\title{
Optimization of Sample Size and DNA Extraction Methods to Improve PCR Detection of Different Propagules of Phytophthora infestans
}

\author{
T. Wangsomboondee and J. B. Ristaino, Department of Plant Pathology, North Carolina State University, Raleigh \\ 27695
}

\begin{abstract}
Wangsomboondee, T., and Ristaino, J. B. 2002. Optimization of sample size and DNA extraction methods to improve PCR detection of different propagules of Phytophthora infestans. Plant Dis. 86:247-253.

The plant pathogen Phytophthora infestans causes a destructive blight of potato tubers and foliage. A rapid polymerase chain reaction (PCR) assay has been developed for detection of $P$. infestans in potato tubers. In this study, the effect of method of DNA extraction on different propagule types and the minimal number of propagules of $P$. infestans detectable by PCR were assessed using the PINF and internal transcribed spacer (ITS) 5 primers. Sensitivity of the primers for PCR was high, and DNA was detectable at concentrations as low as $10 \mathrm{pg} / \mathrm{ml}$. Zoospores and oospores responded differently to different extraction methods, whereas all extraction methods worked equally well for sporangia. Freeze-thaw DNA lysis, in which propagules were frozen at $-80^{\circ} \mathrm{C}$ and thawed at $65^{\circ} \mathrm{C}$ three times for 15 min each, or direct PCR, in which propagules were placed directly in the reaction mix, were effective methods for PCR detection of sporangia or zoospores but were not effective methods for PCR detection of DNA in oospores of $P$. infestans. DNA from a single sporangium or oospore could be amplified by PCR after hexadecyltrimethyl-ammonium bromide (CTAB) or $\mathrm{NaOH}$ lysis extraction methods, whereas DNA from a single zoospore could be amplified by CTAB or direct PCR methods. "IsoCode" Stixs, used in forensic applications, were used to collect the pathogen from leaf and tuber lesions and provided another simple method to extract template DNA. PCR detection of the pathogen in infected tubers using PINF and ITS5 primers was compared to tissue isolation or visual observation. The probability of detection of $P$. infestans in infected tubers at 7 days post inoculation using the PCR assay, tissue isolation, or visual observation was $0.90,0.80$, and 0.75 , respectively. The PINF and ITS5 primers provide a powerful tool for rapid and sensitive detection of zoospores, sporangia, and oospores of $P$. infestans when used with appropriate extraction methods, and could easily be deployed to reduce spread of the pathogen in potato tubers.
\end{abstract}

Phytophthora infestans (Mont.) de Bary, the causal agent of late blight disease, is one of the most devastating pathogens of potato and tomato worldwide and was responsible for the Irish potato famine in the 1840s $(12,13)$. Late blight causes a major foliar disease and tuber blight that can limit yield, tuber quality, and marketability of the crop in the United States and worldwide $(18,26)$. Late blight epidemics, if left uncontrolled, can cause losses up to $100 \%$ when weather conditions are favorable (26). The disease is reemerging in

Corresponding author: J. B. Ristaino

E-mail: Jean_Ristaino@ncsu.edu

Funding for Ms. Wangsoonboondee's assistantship was provided by the Royal Thai Scholars Program, Bangkok, Thailand. The research was supported in part by grants from the National Research Initiatives Competitive Grants Program (95-37313-1941) and in part by a CSREES Special Research Grant for Potato Late Blight from United States Department of Agriculture.

Accepted for publication 15 October 2001.

Publication no. D-2002-0102-05R

(C) 2002 The American Phytopathological Society many areas of the United States and is responsible for costly fungicide application $(6,10,11)$. Epidemics on potato and tomato crops have become severe due to the widespread occurrence of new aggressive and fungicide-resistant strains of $P$. infestans $(6,10,11,14,15)$.

The primary inoculum for late blight in fields is likely associated with infected seed potatoes $(4,29)$. Global migrations of the pathogen have occurred via transport of infected seed tubers (13). During the growing season, tubers can become infected by contact of zoospores carried into the soil by rain (21). Sources of initial inoculum for potato late blight disease in the fields include infected tubers that are used as seed, infected tubers that are discarded prior to or during the season (cull piles), or infected tubers that are not harvested and survive in the soil $(1,2,4,11,18)$. Tubers also can come in contact with infected haulms and contaminated soil at harvest. In storage, healthy tubers can become contaminated with sporangia of $P$. infestans through contact with diseased tubers $(7,16)$. In addition, infected seed tubers cut in the same machine as healthy tubers can spread sporangia to seed pieces and cause disease in fields (20). Improved detection of the pathogen in tubers could reduce spread of the pathogen. Diagnostic laboratories at either state or federal agencies could deploy the polymerase chain reaction (PCR) assay to screen seed potatoes prior to shipping and planting to reduce the spread of new and virulent forms of the pathogen in infected seed potatoes.

Repetitive DNA polymorphism analysis $(19,25)$, oligonucleotide hybridization to amplified ribosomal DNA spacers (23), and PCR amplification of ribosomal DNA and internal transcribed spacer (ITS) regions $(19,24,27,28,30,31)$ have been used to identify the pathogen. PCR-based identification has many advantages over other molecular and traditional isolation methods because the procedure is rapid and less time-consuming $(17,34)$. In plants that can be infected simultaneously by two or more Phytophthora spp., use of PCR can accurately differentiate individual species $(8,24,30)$. Several methods for PCR detection of $P$. infestans in plant material for rapid diagnosis of late blight have been developed $(19,24,30,31)$. In our laboratory, a PCR primer, the PINF primer, was constructed from ITS region DNA and used with ITS5 primer to yield an approximately 600-bp product specific to $P$. infestans (31). In our previous work, the specificity of the primers for $P$. infestans was confirmed using 15 Phytophthora spp. and other pathogens known to infect potato (31). On potato, the primers only amplified DNA of $P$. infestans and not other species of Phytophthora known to infect potato, or host DNA (31)

The specific objective of this study was to optimize DNA extraction methods for zoospores, sporangia, and oospores of $P$. infestans and determine the minimal number of propagules detectable by PCR. In addition, the sensitivity of the PINF and ITS5 primers was evaluated. The minimal time required for detection of $P$. infestans in infected tubers after inoculation, the probability of detection of infected tubers in an artificially inoculated seed lot, and detection of the pathogen in naturally infected tubers from the field also were evaluated. The probability of detection of $P$. infestans by PCR, visual observation, and tissue isolation was calculated and used to optimize sampling strategies. The overall goal of this work is to provide tools that will reduce the risk of spread of $P$. 
infestans in tubers. A portion of this work has been presented previously (33).

\section{MATERIALS AND METHODS}

Pathogen isolates. $P$. infestans isolate 94-1 (US-1 genotype) was collected from diseased tomato in North Carolina in 1994 and used as an A1 mating type for oospore formation. Isolate 93-4 (US-8 genotype) was collected from diseased potato leaves in North Carolina in 1993 and was used as an A2 mating type isolate for oospore formation and also for sporangia and zoospore production, and potato inoculation. Isolates were maintained on Rye B agar (20 g of sucrose, $15 \mathrm{~g}$ of agar, $0.05 \mathrm{~g}$ of $\beta$ sitosterol, rye B broth at $60 \mathrm{ml}$ per liter, and distilled water added up to 1 liter) and stored longterm in $10 \%$ dimethylsulfoxide in cryogenic storage in liquid nitrogen.

DNA extraction. Isolates of $P$. infestans cultured on Rye B agar were transferred to pea broth (120 $\mathrm{g}$ of frozen peas per liter of distilled water) and grown for at least 1 week at $18^{\circ} \mathrm{C}$. Mycelia were harvested by filtration and frozen at $-20^{\circ} \mathrm{C}$. DNA was extracted using a hexadecyltrimethyl-ammonium bromide (CTAB) procedure $(22,31)$. Briefly, the frozen mycelia (10 $\mathrm{mg}$ ) was placed in sterile 1.5 -ml microcentrifuge tubes to which $150-\mu l$ of extraction buffer $(0.35 \mathrm{M}$ sorbital, $0.1 \mathrm{M}$ Tris, 0.005 M EDTA, pH 7.5, $0.02 \mathrm{M}$ sodium bisulfite) was added, and tubes were vortexed. After the addition of nuclei lysis buffer $(150 \mu \mathrm{l})$ containing $0.2 \mathrm{M}$ Tris, $0.05 \mathrm{M}$ EDTA, pH 7.5, 2.0 M NaCl, 2\% CTAB, and $60 \mu \mathrm{l}$ of $5 \%$ sarkosyl (N-lauryl sarcosine), tubes were vortexed and incubated at $65^{\circ} \mathrm{C}$ for 15 to $30 \mathrm{~min}$. After incubation, one volume $(300 \mu \mathrm{l})$ of chloroform:isoamyl alcohol (24:1) was added to each tube and centrifuged for $15 \mathrm{~min}$ at $13,000 \times g$ at room temperature. The aqueous phase was removed to a new tube and chloroform extraction was repeated. DNA was precipitated overnight at $-20^{\circ} \mathrm{C}$ in 0.1 volumes of $3 \mathrm{M}$ sodium acetate $(\mathrm{pH} 8.0)$, and two volumes of cold $100 \%$ ethanol. The supernatant was discarded, and pellets were washed with $70 \%$ ethanol, then dried under vacuum centrifugation. DNA was suspended in TE (10 mM Tris- $\mathrm{HCl}, 0.1$ mM EDTA, pH 8.0).

PCR conditions. PCR was conducted in a $50-\mu$ reaction volume by the procedure of Trout et al. (31). PCR was conducted in thin-walled $0.2-\mathrm{ml}$ tubes. Briefly, $1 \mu \mathrm{l}$ of DNA template (1 ng quantified with a spectrophotometer) was added to a $49-\mu \mathrm{l}$ master reaction mixture containing $5 \mu \mathrm{l}$ of 10× PCR buffer (100 mM Tris-HCl, 15 $\mathrm{mM} \mathrm{MgCl}_{2}$, and $500 \mathrm{mM} \mathrm{KCl}, \mathrm{pH} \mathrm{8.3),}$ $36.6 \mu \mathrm{l}$ of sterile distilled $\mathrm{H}_{2} \mathrm{O}, 1 \mu \mathrm{l}$ of 10 $\mathrm{mM} \mathrm{MgCl} 2,2 \mu \mathrm{l}$ of $2 \mathrm{mM}$ dNTPs, $2 \mu \mathrm{l}$ of $10 \mu \mathrm{M}$ ITS5 primer, $2 \mu \mathrm{l}$ of $10 \mu \mathrm{M}$ PINF primer, and $0.4 \mu \mathrm{l}$ of $\mathrm{Taq}$ polymerase (Boehriger Mannheim Biochemicals, Indianapolis, IN). All reactions were overlaid with sterile mineral oil prior to thermal cycling. The sequences of the PINF and ITS5 primers were 5'-CTCGCTACAATAGGAGGGTC- $3^{\prime}$ and $5^{\prime}$-GGAAGTAAAAGTCGTAACAAGG-3' $\quad(31,34)$, respectively. Thermal cycling parameters were initial denaturation at $96^{\circ} \mathrm{C}$ for $2 \mathrm{~min}$, followed by 35 cycles consisting of denaturation at $96^{\circ} \mathrm{C}$ for $1 \mathrm{~min}$, annealing at $55^{\circ} \mathrm{C}$ for $1 \mathrm{~min}$, and extension at $72^{\circ} \mathrm{C}$ for $2 \mathrm{~min}$. A final extension at $72^{\circ} \mathrm{C}$ for 10 min followed. Electrophoresis of amplified products was conducted on $1.6 \%$ agarose gels containing ethidium bromide at 0.5 $\mu \mathrm{g} / \mathrm{ml}$ with $1 \times$ Tris-borate EDTA running buffer. A 100-bp DNA ladder was included in each gel as a molecular size standard.

Sensitivity of PINF and ITS5 primers. DNA of $P$. infestans was extracted from mycelium using the CTAB method and was quantified using a spectrophotometer. The DNA was diluted to $1,5,10,50,100$, $500,1,000$, and $10,000 \mathrm{pg} / \mu \mathrm{l}$. One microliter of each dilution was used for PCR reactions as described above.

Effect of DNA extraction method on PCR of different propagule types. $P$. infestans was grown for 2 weeks on Rye B agar at $18^{\circ} \mathrm{C}$ in constant light to produce sporangia and zoospores. Water $(10 \mathrm{ml})$ was added to each petri dish containing sporangia and the agar surface was gently rubbed with a glass rod to dislodge sporangia. The sporangial suspension was chilled at 12 to $16^{\circ} \mathrm{C}$ for $80 \mathrm{~min}$ to release zoospores. A cross between isolates 94-1 (A1) and 93-4 (A2) was used to produce oospores. Agar plugs of the A1 and A2 isolates were placed on Rye $\mathrm{B}$ agar medium and incubated in the dark at $18^{\circ} \mathrm{C}$ for 2 to 3 weeks. Oospores were removed from the agar medium after grinding in $20 \mathrm{ml}$ of sterile distilled $\mathrm{H}_{2} \mathrm{O}$ using a blender. Oospore suspensions were digested with lysing enzyme (1 $\mathrm{ml}$ of lysing enzyme and $10 \mathrm{ml}$ of oospores in $\mathrm{H}_{2} \mathrm{O}$ [product no. L2265; Sigma-Aldrich, St. Louis]) at 50 $\mathrm{mg} / \mathrm{ml}$ and incubated at $18^{\circ} \mathrm{C}$ for 20 to $24 \mathrm{~h}$ to lyse sporangia and mycelia in the suspensions. Oospores were harvested by centrifugation and washed with sterile distilled $\mathrm{H}_{2} \mathrm{O}$ until the oospore suspension was determined to be clear of lysed propagules by microscopic observation.

Experiments were conducted to determine the effect of different DNA extraction methods, including $\mathrm{CTAB}, \mathrm{NaOH}$ lysis, freeze-thaw, and direct PCR (no extraction), on zoospores, sporangia, and oospores and to determine the minimal number of each propagule type detectable by PCR. Suspensions consisting of either zoospores, sporangia, or oospores were prepared as described above. Experiments were conducted with a series of dilutions containing $1,10,100$, or 1,000 propagules of each propagule type per PCR reaction mixture. Propagule densities in the initial suspension were quantified on a haemacytometer and appropriate dilutions were prepared to give 100 and 1,000 propagules per tube per PCR reaction. Sporangia (1 or 10) were directly removed from culture plates to tubes with the tip of a needle under a stereomicroscope. Suspensions of zoospores and oospores were spread on water agar plates and individual propagules were selected with the tip of a needle for 1and 10-propagule treatments. Propagule numbers were confirmed by directly counting extra subsamples of each propagule type and concentration with a microscope.

Experiments were conducted to determine the effect of different extraction procedures, including $\mathrm{CTAB}, \mathrm{NaOH}$ lysis, and freeze-thaw lysis, or direct PCR (no extraction) on release of DNA and PCR detection of different propagule types of $P$. infestans. The CTAB extraction procedure was used as describe previously (31). For the $\mathrm{NaOH}$ lysis method, propagules were ground in $10 \mu \mathrm{l}$ of $0.5 \mathrm{~N} \mathrm{NaOH}$ with plastic pestles, after which $5 \mu \mathrm{l}$ was transferred immediately to a sterile $1.5-\mathrm{ml}$ tube containing $495 \mu \mathrm{l}$ of $100 \mathrm{mM}$ Tris, $\mathrm{pH} 8.0$ (32). The suspension $(1 \mu \mathrm{l})$ was added to $49 \mu \mathrm{l}$ of master mix for PCR. For the freeze-thaw lysis method, tubes containing propagules suspended in $\mathrm{H}_{2} \mathrm{O}$ were centrifuged and $\mathrm{H}_{2} \mathrm{O}$ was discarded. Tubes containing propagules were alternatively frozen at $-80^{\circ} \mathrm{C}$ and thawed at $65^{\circ} \mathrm{C}$ in a water bath three times for $15 \mathrm{~min}$ each. For PCR, $49 \mu \mathrm{l}$ of master mixture was added into each tube. For direct PCR, $49 \mu \mathrm{l}$ of master mix was added directly into each tube containing propagules of the pathogen in $1 \mu$ of water.

All DNA extraction experiments were conducted separately for each propagule type. There were three replicate reaction tubes per extraction procedure at each of four propagule levels. The entire experiment was conducted three times. Appropriate nontemplate controls were included in each experiment. Data are presented as the percentage of positive detections by PCR for each propagule level and extraction method. The data for each propagule type was analyzed separately as a factorial with two factors (DNA extraction method, four levels; and number of propagules, four levels). Data were analyzed by analysis of variance using the statistical analysis system (SAS, Inc. Cary, NC).

Experiments also were conducted to determine whether DNA of $P$. infestans could be detected using a simplified extraction method on IsoCode Stixs (Schleicher \& Schuell, Keene, NH). IsoCode Stixs are commonly used in crime lab forensic applications for blood and saliva samples and contain paper impregnated with reagents that bind PCR inhibitors, thus eliminating the need for lengthy DNA extraction procedures. The method described here was from the manufacturer's instructions. A small piece of tissue $\left(1 \mathrm{~cm}^{2}\right)$ containing the late blight pathogen was removed from an infected leaf or tuber 
lesion containing $P$. infestans and the sample was ground in a few drops of water with a Konte pestle. The tissue was placed onto the end of one of the four triangular sample areas of the IsoCode Stix (Fig. 1A). A pure culture of the pathogen was used as a positive control. Samples were dried at $80^{\circ} \mathrm{C}$ for 5 to $10 \mathrm{~min}$ in a hot-air oven. Each sample triangle was placed over a sterile microcentrifuge tube, and the lid was closed while pulling the end of the stick to detach the sample triangle directly into the tube. Then, $50 \mu \mathrm{l}$ of sterile distilled water was added into each tube and the sample was washed by pulse-vortexing three times for at least $5 \mathrm{~s}$ each. The water was removed with a sterile pipette after washing and the tube was centrifuged for $5 \mathrm{~s}$ to remove residual droplets of water. Subsequently, the sample was resuspended in $50 \mu \mathrm{l}$ of sterile distilled water and the tube was incubated at $95^{\circ} \mathrm{C}$ for $30 \mathrm{~min}$ and gently mixed after incubation to release the DNA from the membrane. The water containing the template DNA was removed to a new tube, and 5 to $10 \mu$ of DNA were used for each PCR reaction. Experiments were repeated twice.

Detection of $P$. infestans in infected tubers by PCR, visual observation or tissue isolation. An experiment was conducted to determine the minimum time period before infections could be detected by PCR, visual observation, and tissue isolation. Small pieces of mycelium of $P$. infestans were removed from 3- to 4-weekold petri dishes containing Rye $\mathrm{B}$ agar media and placed into wounds cut into potato tubers with a sterile cork borer. Wounds were sealed by replacing the cut in the tuber with the plug. Inoculated tubers were incubated in moist chambers at $18^{\circ} \mathrm{C}$. Tubers were observed daily for 7 days, and visual symptoms were recorded. Three different tubers were destructively sampled daily for a 7-day period. A sample of infected tissue approximately $2 \mathrm{~cm}$ from the inoculation site was removed and each sample was divided into three pieces. One piece of tissue was extracted using the $\mathrm{NaOH}$ lysis method and used for PCR. The other two pieces of tissue were used for isolation of $P$. infestans. Prior to isolation, tissue was surface disinfected with $0.05 \%$ sodium hypochlorite for $1 \mathrm{~min}$, washed two times with sterile water, and placed on Rye B medium amended with $200 \mathrm{mg}^{-1}$ of vancomycin, $10 \mathrm{mg}^{-1}$ of pimaricin, 100 $\mathrm{mg}^{-1}$ of pentachloronitrobenzene, and 5 $\mathrm{mg}^{-1}$ of hymexazol. Experiments were conducted three times.

An experiment was conducted to determine the probability of detection of the pathogen in an infected seed lot of 100 tubers. One hundred tubers were inoculated with mycelium of $P$. infestans as described above. All tubers were sampled 7 days after inoculation from visible lesions approximately $2 \mathrm{~cm}$ from the inoculation site. Tissue was rated for visual evidence of disease and then divided in half and used for either PCR assays or tissue isolations as described above. Tissue (20 $\mathrm{mg}$ ) was sampled from lesions on each tuber, and $\mathrm{NaOH}$ lysis was used to extract the DNA as described above. The experiments were repeated two times.

In each experiment, the probability of detection of infected tubers in the infected seed lot $(\mathrm{Pd})$ was calculated as follows: $\mathrm{Pd}_{i}$ containing $P$. infestans $/ 100$. The average of the two experiments, $\mathrm{Pd}=\left(\mathrm{Pd}_{1}+\mathrm{Pd}_{2}\right) / 2$, along with its standard error (SE) is reported. Using the $\mathrm{Pd}$, we can compute the probability of detecting at least one infected tuber from any lot of tubers as a function of the number of tubers in the lot $(N)$, the number of infected tubers in the lot, and the sample size $(n)$. The number of infected tubers that we would expect to detect is $N_{1}=$ number infected $\times \mathrm{Pd}$. The probability that a sample of $n$ tubers from this lot contains at least one detectable infected tuber is found from the hypergeometric distribution, and is $\operatorname{Pr}($ detect at least one infected tuber $)=1-\left(\left[N_{1} / 0\right][N-\right.$ $\left.\left.N_{1}\right] / n\right) /(N / n)(5)$. We constructed a table of sample sizes needed to be able to detect at least one infected tuber with at least 80 or $90 \%$ probability.

Detection of $P$. infestans in naturally infected tubers. Four potato seed lots $=$ number of positive tubers detected

were collected from potato growers in North Carolina prior to planting in February 1997 and were used to determine whether $P$. infestans was present in seed potatoes. The seed potato sampled originated from various seed-growing regions of the United States and Canada, including Maine, Wisconsin, and New Brunswick. Approximate 100 tubers collected randomly from each of four seed lots (cv. Atlantic) were used in subsequent experiments.

Tubers were washed, blotted dry, and incubated in moist chambers at $18^{\circ} \mathrm{C}$ for 2 weeks. Visible late blight symptoms were not observed on tubers at the time of sampling. Tissue $(20 \mathrm{mg})$ was randomly sampled from each tuber, and $\mathrm{NaOH}$ lysis was used to extract the DNA as described above. One PCR assay was conducted on each of the sampled tubers to identify infected tubers. Visible lesions were not present on the tubers; therefore, samples were taken randomly on the tuber. Experiments were repeated twice.

Tubers also were sampled from the National Late Blight Fungicide Trial conducted in 1997 by Mary Powelson at Oregon State University. The fungicides Acrobat MZ (2.52 kg/ha), Tattoo C (2.69 liters $/ \mathrm{ha})$, and Curzate $(0.23 \mathrm{~kg} / \mathrm{ha})+$ Manzate $(1.96 \mathrm{~kg} / \mathrm{ha})$, were evaluated for abil-
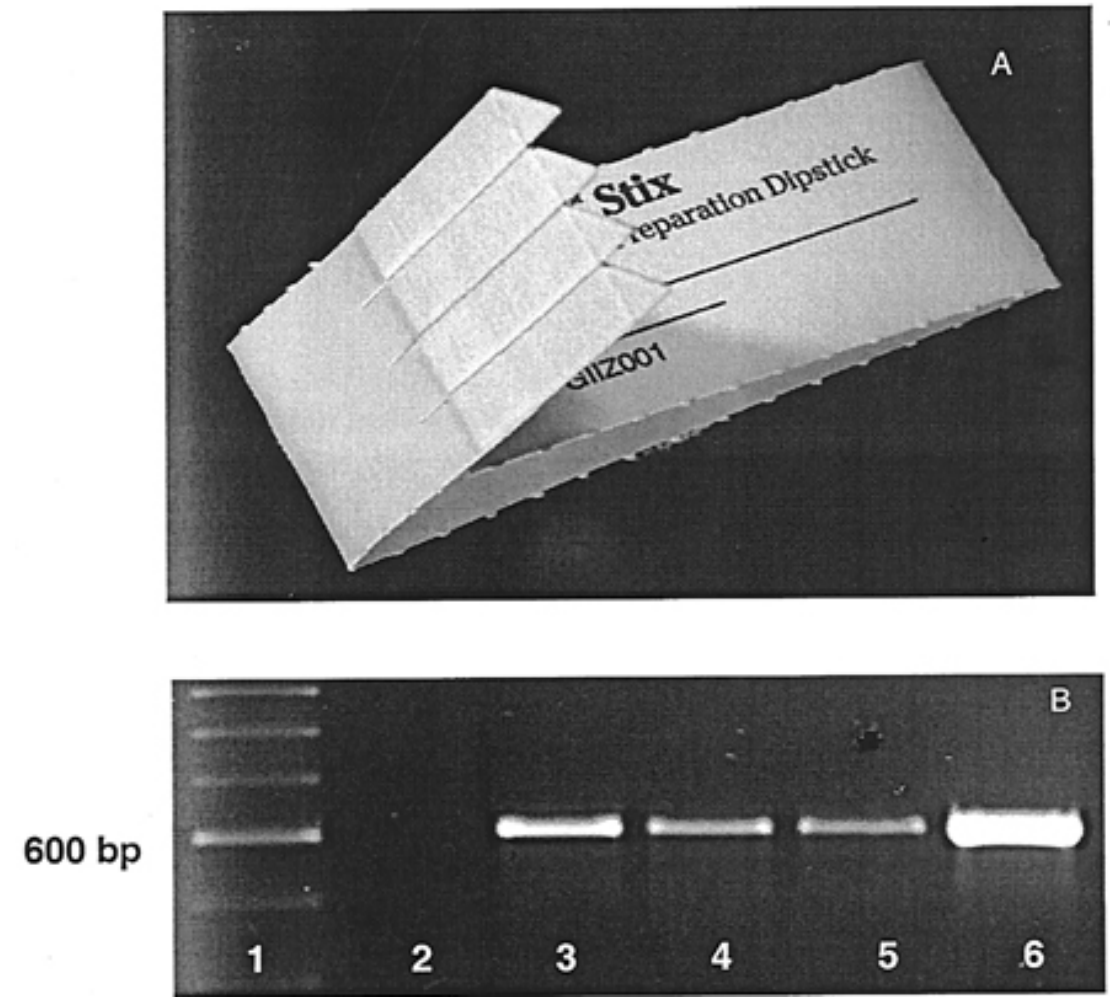

Fig. 1. A, Sample collection matrix of IsoCode Stixs designed to isolate DNA to be used as template for polymerase chain reaction (PCR). The base paper for IsoCode is grade 903 paper composed of cotton linter (Schleicher \& Schuell, Keene, NH). The papers are impregnated with reagents that bind PCR inhibitors and release DNA in a simple water solution. B, PCR amplification of Phytophthora infestans DNA by IsoCode Stix extractions. Lane 1, 100-bp DNA ladder; lane 2, no template control; lanes 3-5 contain amplified DNA products from Isocode Stixs extracted from mycelium of $P$. infestans, tubers, and leaf lesions, respectively; lane 6, DNA product derived from PCR of $P$. infestans DNA from hexadecyltrimethyl-ammonium bromide extraction (positive control). 
ity to control late blight of potatoes on the Lewis Brown Horticultural Research Farm near Corvallis, OR. Potato was planted and inoculated with $P$. infestans (US-8) by applying an aerosol suspension of the pathogen in the spreader rows. Fungicide applications were initiated 15 days after inoculation. A subsample of 50 tubers from each of three fungicide treatments and a nontreated control were shipped to North Carolina State University (NCSU) after harvest. The tubers were washed, blotted dry, and incubated in moist chambers at $18^{\circ} \mathrm{C}$ for 2 weeks to encourage lesion development. Tubers then were observed for visual evidence of disease and a sample (1 $\mathrm{cm}^{3}$ ) was removed from the lesion and tested by the PCR assay in our laboratory after $\mathrm{NaOH}$ lysis of the tissue (32). Tubers also were sampled from a second, similar fungicide test conducted in 1998 at Upper Mountain Research Station in Laurel Springs, NC. Tubers were sampled from the same fungicide treatments. Tubers were incubated as described above and evaluated by the PCR assay and visual inspection. Tubers in the Laurel Springs test did not have symptoms of the disease.

\section{RESULTS}

Sensitivity of PINF primer. The targeted DNA of $P$. infestans was amplified by PCR using PINF and ITS5 primers at concentrations of template DNA as low as $10 \mathrm{pg} / \mu \mathrm{l}$ (Fig. 2). DNA was not amplified when the template DNA was reduced to concentrations of 5 or $1 \mathrm{pg} / \mu \mathrm{l}$ (Fig. 2).

Effect of DNA extraction method on PCR detection of different propagule types. The percentage of positive PCR detections varied with extraction method and number of propagules for zoospores and oospores of $P$. infestans (Table 1, Fig. 3). DNA from single zoospores of $P$. infestans was successfully amplified by PCR after CTAB extraction or direct PCR but not by $\mathrm{NaOH}$ lysis or freeze-thaw lysis methods (Fig. 3A). In contrast, the percentage of positive PCR detections for DNA extracted from sporangia was not affected by extraction method but increased as the number of sporangia in the sample increased (Fig. 3B, Table 1). Extraction method had a large effect on the percentage of positive PCR detections from oospores. DNA from single oospores was detected by PCR after CTAB and $\mathrm{NaOH}$ lysis, but DNA from oospores was not detected by PCR after freeze-thaw lysis or by direct PCR at any level of oospores (Fig. 3C). The latter methods may not have successfully lysed the oospore walls to release DNA.

DNA template of $P$. infestans from either infected tubers, leaf lesions, or mycelium was successfully amplified by PCR

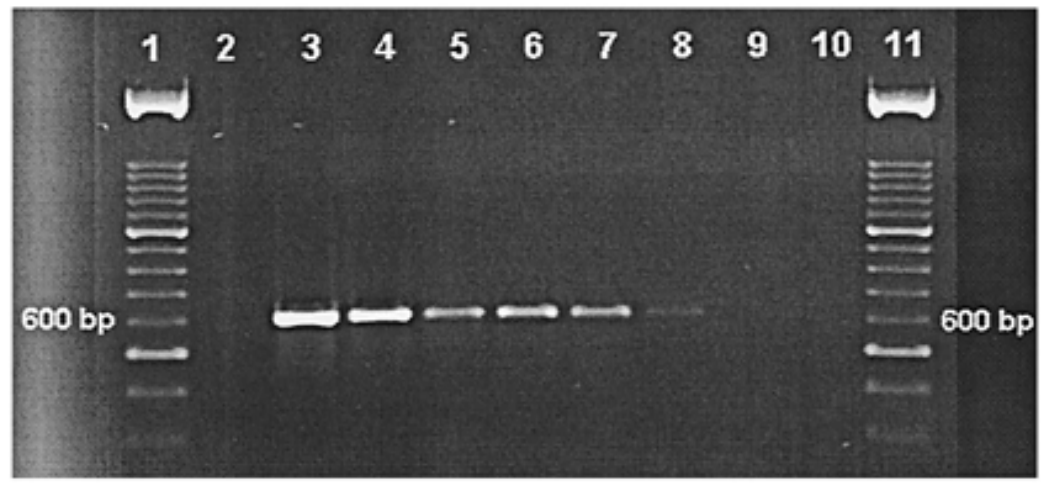

Fig. 2. Detection of Phytophthora infestans DNA using the PINF and internal transcribed spacer (ITS)5 primers. Lanes 1 and 11, 100-bp DNA ladder; lane 2, no template control; lanes 3-10, P. infestans template DNA at concentration of $10,000,1,000,500,100,50,10,5$, and $1 \mathrm{pg} / \mu \mathrm{l}$, respectively.

Table 1. Analysis of variance of the effect of DNA extraction method and propagule number on polymerase chain reaction (PCR) detection of DNA from sporangia, zoospores or oospores of Phytophthora infestans

\begin{tabular}{|c|c|c|c|c|}
\hline \multirow[b]{2}{*}{ Source of variation } & \multirow[b]{2}{*}{ df } & \multicolumn{3}{|c|}{ Probability $>F^{\mathrm{w}}$} \\
\hline & & Sporangia & Zoospores & Oospores \\
\hline DNA extraction method (extract) & 3 & 0.9437 & $0.0218 *$ & $0.0001 *$ \\
\hline Number of propagules (number) ${ }^{\mathrm{y}}$ & 3 & $0.0001 *$ & $0.0001 *$ & $0.0001 *$ \\
\hline Number $\times$ extract & 9 & 0.8582 & $0.0079 *$ & $0.0002 *$ \\
\hline $\operatorname{Rep}^{\mathrm{z}}$ & 2 & $0.0291 *$ & 0.3332 & 0.0547 \\
\hline
\end{tabular}

${ }^{\mathrm{w}} P>F$ is the probability value greater than the $\mathrm{f}$ statistic in the analysis of variance; $*$ indicates the values are significant at $P<0.05$ or less.

${ }^{x}$ DNA extraction methods included hexadecyltrimethyl-ammonium bromide, $\mathrm{NaOH}$ lysis, freezethaw lysis, and direct PCR (no extraction).

${ }^{y}$ Numbers of propagules from each propagule type consisted of 1,10,100, and 1,000 propagules.

${ }^{z}$ There were three replicate tubes per DNA extraction method at each level of propagules. from IsoCode Stixs using the simple methods provided by the manufacturer and the PINF and ITS5 primers (Fig. 1).

Detection of $P$. infestans in infected tubers by PCR, visual observation, or tissue isolation. Symptoms did not become obvious until 3 days after inoculation. $P$. infestans was positively detected in only 22, 22, and $44 \%$ of asymptomatic, artificially inoculated tubers 3 days after inoculation by either PCR, visual observation, or tissue isolation, respectively. However, 4 days after inoculation, the percent positive detections were $100 \%$ by both PCR and visual observation and $89 \%$ by tissue isolation. After 4 days, when symptoms became apparent, detection was $100 \%$ by all methods.

Symptomatic tissue from 100 artificially inoculated tubers was assayed 7 days after inoculation by PCR assay, visual observation, and tissue isolation, and the probability of infected tubers containing $P$. infestans was estimated to be 0.90 ( $\mathrm{SE}=$ $0.007), 0.75(\mathrm{SE}=0.014)$, and $0.80(\mathrm{SE}=$ 0.071 ), respectively. $P$. infestans was detected at significantly higher levels by PCR than by visual observation or tissue isolation.

Using a Pd of $90 \%$, we computed the Pd of at least one infected tuber in an infected seed lot 7 days after inoculation for lots with different numbers of infected tubers and different sample sizes. For a lot of 400 tubers, the sample size needed to detect at least one infected tuber with a probability of $90 \%$ is given in Table 2 .

Detection of $P$. infestans in naturally infected tubers. None of the tubers assayed from North Carolina growers' stored seed lots were positive for $P$. infestans by PCR or visual observation. However, infected tubers from the National Late Blight Fungicide Trail conducted in 1997 at Oregon State University were tested with the PINF and ITS5 primers and the pathogen was detected in some of these tubers (Table 3). Tubers from control plots with no fungicide treatment had the lowest percentage of infected tubers as indicated by both visual observation and PCR assays. The incidence of disease was significantly higher in tubers from fungicidetreated plots than in tubers from nontreated control plots $(P<0.05)$. The percentage of infected tubers determined by visual observation and PCR were not significantly different. However, the incidence of disease in tubers as determined by visual observation was slightly higher than the incidence of disease determined by PCR. No infected tubers were found by either visual observation or PCR assay in the asymptomatic tubers from the 1998 field test conducted in Laurel Springs, NC.

\section{DISCUSSION}

DNA from $P$. infestans was detectable at a concentration as small as $10 \mathrm{pg} / \mu \mathrm{l}$ using the PCR assay with PINF and ITS5 prim- 
ers. Others have used our assay and reported detection of $1 \mathrm{pg} / \mu \mathrm{l}$ when a colorimetric assay was used to detect the amplified products (Jim Beck, Novartis Chemical Company, personal communication). The PINF and ITS5 primers were as sensitive as the primers reported by Tooley et al. (30) for detection of $P$. infestans but not as sensitive as the primers recently reported by Judelson and Tooley (19).
Niepold and Schöber-Butin (24) also developed primers for detection of $P$. infestans from repetitive DNA sequences and studied their sensitivity. However, their results cannot be compared with ours because they did not quantify DNA template concentrations. Detection of lower concentrations of DNA and increased sensitivity with the PINF and ITS5 primers could be achieved if southern blot hybridi-

\section{Zoospores}

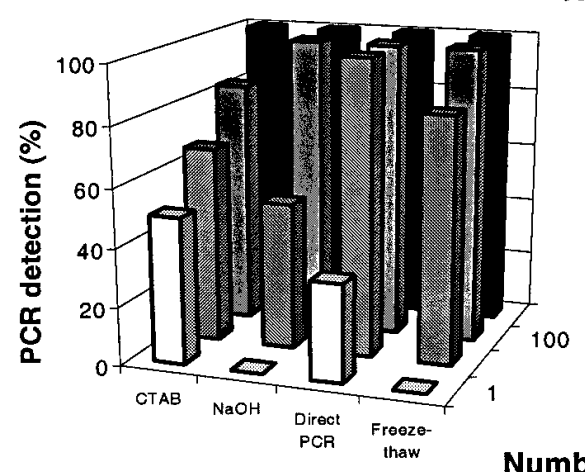

Extraction method

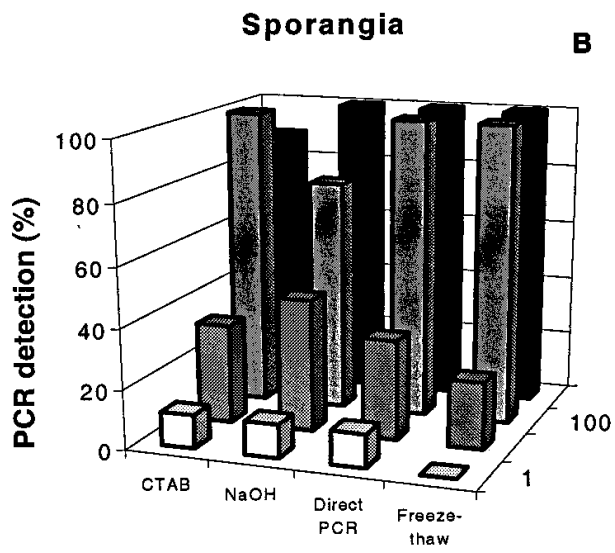

Extraction method

Number of spores

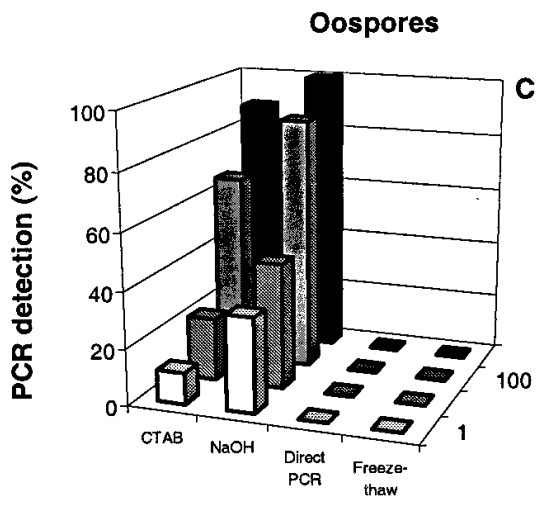

Extraction method

Fig. 3. Detection of Phytophthora infestans DNA extracted from A, zoospores, B, sporangia, and $\mathbf{C}$, oospores using the PINF and internal transcribed spacer (ITS)5 primers over a range of propagule numbers. DNA templates were derived from hexadecyltrimethyl-ammonium bromide, $\mathrm{NaOH}$ lysis, freeze-thaw lysis, or direct polymerase chain reaction (no extraction) methods. zation, colorimetric assays, or nested PCR assays were used $(3,9,30)$.

Extraction methods were optimized in our study to improve PCR detection of specific propagule types of $P$. infestans. Our data clearly indicate that the lower threshold level for detection of DNA from various propagule types by PCR is dependant upon the DNA extraction method used and the propagule type. Some propagules, such as oospores, are more recalcitrant to DNA extraction and require full CTAB DNA extraction or lysis with $\mathrm{NaOH}$ before PCR is possible. When extraction methods were optimized, single propagules of all spore types could be detected using the PINF and ITS5 primers. It is important, from a biological perspective, to consider the effects of extraction methods used on subsequent PCR rather than only the minimum sensitivity levels of various primers (19), because extraction method can have a large impact on the quantity and quality of DNA and the success of the PCR reactions. In plant tissues, infections could potentially contain multiple propagule types of the pathogen, and DNA concentrations in

Table 2. Sample sizes needed to detect at least one tuber infected with Phytophthora infestans with a probability of 80 or $90 \%$ in a potato seed lot with various number of infected tubers ${ }^{\mathrm{z}}$

\begin{tabular}{lcc}
\hline \multirow{2}{*}{$\begin{array}{l}\text { No. of infected } \\
\text { tubers }\end{array}$} & \multicolumn{2}{c}{ Sample size per probability } \\
\cline { 2 - 3 } & $\mathbf{8 0 \%}$ & $\mathbf{9 0 \%}$ \\
\hline 5 & 110 & 147 \\
10 & 65 & 90 \\
15 & 43 & 60 \\
20 & 34 & 48 \\
25 & 27 & 38 \\
30 & 23 & 32 \\
35 & 19 & 27 \\
40 & 17 & 24 \\
\hline
\end{tabular}

${ }^{\mathrm{z}}$ Lot size $=400$ tubers, probability of detection $=0.90$.

Table 3. Effect of fungicide treatment on the incidence of potato tubers infected with Phytophthora infestans by visual observation and polymerase chain reaction (PCR) assay

\begin{tabular}{lcc}
\hline & \multicolumn{2}{c}{ Infected tubers $(\%)^{\mathrm{y}}$} \\
\cline { 2 - 3 } Treatment & $\begin{array}{c}\text { Visual } \\
\text { observation }\end{array}$ & $\begin{array}{c}\text { PCR } \\
\text { assay }\end{array}$ \\
\hline Control & $0 \mathrm{~b}$ & $1.67 \mathrm{~b}$ \\
Acrobat MZ & $36.38 \mathrm{a}$ & $27.37 \mathrm{a}$ \\
Tattoo C & $51.67 \mathrm{a}$ & $40.84 \mathrm{a}$ \\
Curzate + Manzate & $44.00 \mathrm{a}$ & $35.00 \mathrm{a}$ \\
\hline y & Means followed by the same letter are not \\
significantly different according to Fisher's \\
protected least significant difference $(P<$ \\
0.05). \\
z A subset of 50 naturally infected tubers from \\
each of four fungicide treatments were sent to \\
North Carolina State University by Mary \\
Powelson from the National Late Blight \\
Fungicide Trial conducted at Oregon State \\
University in 1997. Visual observation of \\
infection in tubers was evaluated on the same \\
tubers that were subjected to the PCR assay.
\end{tabular}


well-colonized tissue would be expected well above the $10 \mathrm{pg} / \mu \mathrm{l}$ threshold of our assay.

The PINF primer was useful for detection of single propagules of either zoospores, sporangia, or oospores of $P$. infestans when used with the appropriate extraction method. DNA from sporangia was easily extracted using all methods, but DNA from zoospores and oospores was more sensitive to extraction method. DNA from oospores was not detected by direct PCR or freeze-thaw lysis methods. These methods may have failed to lyse the oospore walls sufficiently to release DNA. $\mathrm{NaOH}$ lysis and CTAB extraction methods were an efficient method for DNA extraction from oospores. In contrast, direct PCR and freeze-thaw lysis methods were useful for detection of zoospores and sporangia at higher inoculum levels. There are advantages to the direct PCR and freeze-thaw lysis methods, because they are simple, require no chemicals, and all DNA is retained in the sample tube. The $\mathrm{NaOH}$ lysis is less laborious than CTAB extraction but is not as well suited for longterm maintenance of DNA samples.

ITS DNA from single oospores, sporangia, and zoospores of $P$. infestans was amplified using PCR with the PINF and ITS5 primers. PCR is known to be extremely sensitive and others have used the technique to amplify ribosomal DNA (rDNA) from single spores of Neurospora tetrasperma (22). Amplification and analysis of DNA from single propagules could be useful for studies of recombination frequencies in propagules that are difficult to germinate, such as oospores of $P$. infestans. Resting spores of Plasmodiophora brassicae in potting mix soils were detected using PCR and the $\mathrm{NaOH}$ lysis method of DNA extraction (9). Detection of oospores of Phytophthora infestans in soil also could be possible using the methods described in this paper.

IsoCode Stixs provided a useful method for DNA collection and extraction from late blight-infected tubers and leaf tissues from field samples. DNA templates prepared from IsoCode Stixs extractions were adequate for PCR amplification of rDNA. Any gene of interest, including mitochondrial DNA, could be amplified from samples with the simplified methods and other primers. The IsoCode Stixs have advantages for sample collection from fields, because the cards are simple and easy to handle, require no chemicals, and eliminate the need to bring infected tubers or tissues into the laboratory. Air drying tissue for $3 \mathrm{~h}$ on the IsoCode Stixs in the field can be substituted for the hot-air oven drying of samples and is also described in the manufacturer's instructions (unpublished data). We did not test the sensitivity of detection of DNA on the IsoCode Stixs, but their wide application in human forensic work suggests that very low levels of
DNA may be detectable and justifies further evaluation of this method of sample collection for DNA analysis in plant pathogen studies. The obvious limitation of the method is that, because the pathogen is not obtained in pure culture from tissue samples, repeated extractions or assays that require large amounts of DNA, such as restriction fragment length polymorphism, analysis are not possible.

The Pd of P. infestans in an artificially infected seed lot by PCR assay was higher than the Pd by tissue isolation or visual inspection. Traditional isolation of the pathogen on culture media is time consuming because the pathogen grows slowly and contamination is frequent. Visual observations of disease may be misleading because other pathogens can cause similar symptoms in tubers. The PCR assay was sensitive and, using statistical calculations, we were able to predict the optimum sample size to detect at least 1 infected tuber in a seed lot of 400 tubers using the Pd by PCR as 0.90. With increased number of infected tubers in the lot, the sample size required to detect infected tubers decreases (Table 2). There is a need for further testing and deployment of PCR detection methods for seed potato certification to reduce the transmission of new and more aggressive strains of $P$. infestans in tubers (14). Currently, potato tubers are visually inspected for evidence of late blight, and symptoms of the disease can be misdiagnosed or masked by other tuber rotting pathogens.

The PCR assay was useful for detection of the pathogen in naturally infected tubers from the Oregon field trial. In naturally infected tubers with visual symptoms, detection by visual observations was slightly higher than by PCR. We incubated the tubers for 2 weeks before the assay to obtain clearly visible lesions. Overestimation of disease by visual observation may have been possible in our tests. On the other hand, underestimation by PCR may have occurred due to sampling variation or presence of bacteria that degrade DNA in the samples. Detection of infected tubers by PCR is more accurate than visual observation, because other potato pathogens may rot tubers and form lesions that can be misdiagnosed or symptoms may be absent altogether (30).

Tuber blight was not controlled with foliar fungicides in the tests conducted at the Lewis Brown Horticulture Research Farm in Oregon in 1997. The length of sporulation time and potential for propagules to wash down to the soil were greater in plants from fungicide-treated plots than in plants from nontreated control plots, because the rate of epidemics was slower in fungicide-treated plots. Inoculum was produced over a longer period of time in the fungicide-treated than in nontreated control plots. Plants in control plots that were not treated with fungicides died be- fore tuber infection occurred. These factors could explain why tubers from control plots had a lower percentage of infected tubers than tubers from fungicide-treated plots (Mary Powelson, personal communication). In contrast, in an NCSU study in 1998, late blight was found on aboveground plant parts but was not observed on tubers using either visual observation or PCR assay. These results may be due to the differences in soil types, microorganisms in soil, and rainfall levels during the experiment, which can affect the spread of $P$. infestans inoculum from leaves to tubers in soil $(1,21)$.

The PCR detection method described here for $P$. infestans could be used as a practical screen for detection of latent infections caused by the pathogen in potato seed lots prior to storage, shipping, or planting. Rotted tubers in storage are difficult to diagnose by traditional methods. The accurate diagnosis of late blight in seed tubers could assist certification agencies in the potato seed industry which currently do not certify for the pathogen. Tubers that are pathogen-free should reduce movement of late blight pathogen between fields and, ultimately, improve disease management.

\section{ACKNOWLEDGMENTS}

We thank P. Shoemaker, M. Cubeta, and the late C. L. Campbell for guidance as committee members; C. Trout Groves and G. Parra for useful discussions on aspects of this work; M. Powelson at Oregon State University for providing late blight-infected potato tubers for the work from her fungicide trial; and M. Gumpertz, Department of Statistics, for assistance with sampling statistics.

\section{LITERATURE CITED}

1. Andrivon, D. 1994. Dynamics of survival and infectivity to potato tubers of sporangia of Phytophthora infestans in three different soils. Soil Biol. Biochem. 26:945-952.

2. Andrivon, D. 1995. Biology, ecology, and epidemiology of the potato late blight pathogen Phytophthora infestans in soil. Phytopathology 85:1053-1056.

3. Beck, J. J., Beebe, J. R., Stewart, S. J., Bassin, C., and Etienne, L. 1996. Colorimetric PCR and ELISA diagnostics for detection of Pseudocercosporella herpotrichoides in field samples. Brighton Crop Prot. Conf. Pest Dis. 221-226.

4. Boyd, A. E. W. 1980. Development of potato blight (Phytophthora infestans) after planting infected seed tubers. Ann. Appl. Biol. 95:301309.

5. Casella, G., and Berger, R. L. 1990. Statistical Inference. Wadsworth, Belmont, CA.

6. Deahl, K. L., DeMuth, S. P., Linden, S. L., and Rivera-Pena, A. 1995. Identification of mating types and metalaxyl resistance in North American populations of Phytophthora infestans. Am. Pot. J. 72:35-49.

7. Dowley, L. J., and O'Sullivan, E. 1991 Sporulation of Phytophthora infestans (Mont.) de Bary on the surface of diseased potatoes and tuber spread of infection during handling. Potato Res. 34:295-297.

8. Ersek, T., Schoelz, J. E., and English, J. T. 1994. PCR amplification of species-specific DNA sequences can distinguish among Phytophthora species. Appl. Environ. Microbiol. 
60:2616-2621.

9. Faggian, R., Bulman, S. R., Lawrie, A. C., and Porter, I. J. 1999. Specific polymerase chain reaction primers for the detection of Plasmodiophora brassicae in soil and water. Phytopathology 89:392-397.

10. Fraser, D. E., Shoemaker, P. B., and Ristaino, J. B. 1999. Characterization of isolates of Phytophthora infestans from tomato and potato in North Carolina from 1993 to 1995. Plant Dis. 83:633-638.

11. Fry, W. E., and Goodwin, S. B. 1997. Resurgence of the Irish potato famine fungus. BioScience 47:363-371.

12. Fry, W. E., Goodwin, S. B., Dyer, A. T., Matuszak, J. M., Drenth, A., Tooley, P. W., Sujkowski, L. S., Koh, Y. J., Cohen, B. A., Spielman, L. J., Deahl, K. L., Inglis, D. A., and Sandlen, K. P. 1993. Historical and recent migrations of Phytophthora infestans: chronology, pathways, and implications. Plant Dis. 77:653-661.

13. Fry, W. E., Goodwin, S. B., Dyer, A. T., Matuszak, J. M., Spielman, L. J., and Milgroom, M. G. 1992. Population genetics and intercontinental migrations of Phytophthora infestans. Annu. Rev. Phytopathol. 30:107-129.

14. Goodwin, S. B., Smart, C. D., Sandrock, R. W., Deahl, K. L., Punja, Z. K., and Fry, W. E. 1998. Genetic change within populations of Phytophthora infestans in the United States and Canada during 1994 to 1996: role of migration and recombination. Phytopathology 88:939-949.

15. Goodwin, S. B., Sujkowski, L. S., and Fry, W. E. 1996. Widespread distribution and probable origin of resistance to metalaxyl in clonal genotypes of Phytophthora infestans in the United States and Western Canada. Phytopathology 86:793-800.

16. Henricksen, J. B. 1974. Transmission of late blight (Phytophthora infestans (Mont.) de
Bary by contract with potato tubers during storage. Tidsskr. Planteavl. 78:18-22.

17. Henson, J. M., and French, R. 1993. The polymerase chain reaction and plant disease diagnosis. Annu. Rev. Phytopathol. 31:81-109.

18. Hirst, J. M., and Stedman, O. J. 1960. The epidemiology of Phytophthora infestans. II. The source of inoculum. Ann. Appl. Biol. 48:489-517.

19. Judelson, H. S., and Tooley, P. W. 2000. Enhanced PCR methods for detection and quantification of Phytophthora infestans in plants. Phytopathology 90:1112-1115.

20. Lambert, D. H., Currier, A. I., and Olanya, M. O. 1998. Transmission of Phytophthora infestans in cut potato seed. Am. J. Potato Res. 75:257-263.

21. Lapwood, D. H. 1977. Factors affecting the field infection of potato tubers of different cultivars by blight (Phytophthora infestans). Ann. Appl. Biol. 85:23-42.

22. Lee, S. B., and Taylor, J. W. 1990. Isolation of DNA from fungal mycelium and single spores. Pages 282-287 in: PCR Protocols: A Guide to Methods and Applications. M. A. Innis, D. H. Gelfand, J. J. Sninsky, and T. J. Thomas, eds. Academic Press, San Diego, CA.

23. Lee, S. B., White, T. J., and Taylor, J. W. 1993. Detection of Phytophthora species by oligonucleotide hybridization to amplified ribosomal DNA spacers. Phytopathology 83:177-181.

24. Niepold, F., and Schöber-Butin, B. 1995. Application of PCR technique to detect Phytophthora infestans in potato tubers and leaves. Microbiol. Res. 150:379-385.

25. Panabieres, F., Marais, A., Trentin, F., Bonnet, P., and Ricci, P. 1989. Repetitive DNA polymorphism analysis as a tool for identifying Phytophthora species. Phytopathology 79:1105-1109.

26. Platt, H. W., Peters, R. D., Medina, M., and
Arsenault, W. 1999. Impact of seed potatoes infected with Phytophthora infestans (US-1 or US-8 genotypes) on crop growth and disease risk. Am. J. Pot. Res. 75:67-73.

27. Ristaino, J. B., Groves, C. T., and Parra, G. 2001. PCR Amplification of the Irish Potato Famine Pathogen from Historic Specimens. Nature 411:695-697.

28. Ristaino, J B., Madritch, M., Trout, C. L., and Parra, G. 1998. PCR amplification of ribosomal DNA for species identification in the plant pathogen genus Phytophthora. Appl. Environ. Microbiol. 64:948-954.

29. Stevenson, W. R. 1993. Management of early and late blight. Pages 141-147 in: Potato Health Management. R. C. Rowe, ed. American Phytopathological Society Press, St. Paul, MN.

30. Tooley, P. W., Bunyard, B. A., Carras, M. M., and Hatziloukas, E. 1997. Development of PCR primers from internal transcribed spacer region 2 for detection of Phytophthora species infecting potatoes. Appl. Environ. Microbiol. 63:1467-1475.

31. Trout, C. L., Ristaino, J. B., Madritch, M. and Wangsomboondee, T. 1997. Rapid detection of Phytophthora infestans in late blight potatoes and tomatoes using PCR Plant Dis. 81:1042-1048.

32. Wang, H., Qi, M., and Cutler, A. J. 1993. A simple method of preparing plant samples for PCR. Nucleic Acids Res. 21:4153-4154.

33. Wangsomboondee, T., and Ristaino, J. B 1998. Detection of Phytophthora infestans in potato tubers. (Abstr.) Phytopathology 88:S95.

34. White, T. J., Burns, T., Lee, S., and Taylor, J. 1990. Amplification and direct sequencing of fungal ribosomal RNA genes for phylogenetics. Pages 315-322 in: PCR Protocols: A Guide to Methods and Applications. M. A. Innis, D. H. Gelfand, J. J. Sninsky, and T. J. White, eds. Academic Press, San Diego, CA. 